\title{
SISTEM INFORMASI PENGOLAHAN DATA ANAK PONDOK PESANTREN ULAKAN KEC.LUBUK TAROK
}

\author{
Okta Andrica Putra ${ }^{1}$, Harkamsyah andrianof $^{2}$, Aggy Pramana Gusman $^{3}$ \\ ${ }^{123}$ Fakultas Ilmu Komputer, Universitas Putra Indonesia "YPTK" Padang, Jl Lubuk Begalung Padang \\ email: oktaandrica@gmail.com, harkamsyah.andrianof@upiyptk.ac.id,Apgusman@gmail.com
}

\begin{abstract}
Pondok Pesantren Ulakan Kec.Lubuk Tarok merupakan suatu pondok pesantren , memiliki anak didik berjumlah kurang lebih 100 orang yang tinggal di asrama tersebut. Administrasi keasramaan harus memiliki seluruh data anak dengan lengkap, sehingga seluruh data harus dikelola dengan menggunakan teknologi komputer. Penelitian ini bertujuan memudahkan administrasi dalam mengelola dataanak pondok pesantren sehingga dapat menghasilkan laporan data anak pondok pesantrenyang lebih efektif dan efisien dan dapat menjamin keamanan data dalam waktu jangka panjang. Dalam penelitian ini, peneliti mengunakan metode deskriptif yaitu dengan mengumpulkan data dan informasi Pesantren Ulakan Kec.Lubuk Tarok. Implementasi program menggunakan bahasa Pemrograman PHP dengan database MySQL. Dengan penerapan sistem yang baru pada Podok Pesantren, laporan pengolahan data yang dihasilkan menjadi lebih lebih efektif dan efesien, Sistem yang baru dapat mempermudah dan mempercepat proses kerja dari bagian administrasi dalam mengolah data yang ada pada Pondok Pesantren Ulakan Kec.Lubuk Tarok, Proses Pengarsipan dokumen yang teratur dan rapi sehingga meminimalisir kemungkinan untuk kehilangan data
\end{abstract}

Keywords: administrasi, asrama, data, php dan mysql

\section{PENDAHULUAN}

Pondok Pesantren Ulakan Kec.Lubuk Tarokmerupakan suatu pondok pesantren , memiliki anak didik berjumlah kurang lebih 100 orang yang tinggal di asrama tersebut. Administrasi keasramaan harus memiliki seluruh data anak dengan lengkap, sehingga seluruh data harus dikelola dengan menggunakan teknologi komputer.

Pondok Pesantren Kec.Lubuk Tarok membutuhkan Sistem Informasi Pengolahan DataAnakPesantren,karena saat ini pihak pondok pesantren kesulitan dalam mengolah data anak pondok pesantren. Pengolahan data anak pondok pesantren dilakukan dengan Microsoft Excel sehingga laporan-laporan yang dihasilkan tidak efektif dan efisien. Sistem pengarsipan tidak terstruktur dan sulit menemukan kembali data yang dibutuhkan.Kendala lainnya adalah keterbatasan dalam pengolahan data, sehingga menyebabkan bagian administrasi kesulitan dalam membuat laporan-laporan dan membutuhkan waktu yang lama dalam menyelesaikannnya.

Dengan adanya sistem informasi diharapkan dapat membantu pihak pondok pesantren dalam mengelola dan mengolah data anak pondok pesantren. Mulai dari pendataan anak yang tempat tinggal di dalam pondok, pendata ananak pondok pesantren yang tempat tinggalnya di luar pondok pesantren, pendataan tanggal masuk anak pondok, pendataan guru pondok pesantren, serta informasi informasi penting tentang anak pondok pesantren.

Menurut Fatansyah bahwadata adalah "representasi fakta dunia nyata yang mewakili sebuah objek seperti manusia (Pegawai, Siswa, Pembeli, Pelanggan), barang,hewan, pristiwa, konsep, keadaan dan sebagainya, yang diwujudkan dalam bentuk angka,huruf, symbol, teks, gambar, bunyi atau kombinasinya". 
Menurut Tata Sutabri (2012:224) bahwa perancangan sistem merupakan "prosedur untuk mengkonversi spesifikasi logis ke dalam sebuah desain yang dapat diimplementasikan pada sistem komputer organisasi”.

Menurut Rossa dan M. Salahuddin (2013:23) bahwa "desain atau perancangan dalam pembangunan perangkat lunak merupakan upaya untuk mengontruksikan sebuah system yang memberikan kepuasan(mungkin informal)akan spesifikasi kebutuhan fungsional, memenuhi target, memenuhi kebutuhan secara implisit dan ekplisit dari segi ferfomansi maupun penggunaan sumber daya, kepuasan batasan pada proses disain dari segi biaya, waktu dan perangkat".

Menurut Rosa dan M. Salahuddin (2013:18) bahwa analisis sistem adalah "kegiatan untuk melihat sistem yang sudah berjalan, melihat bagian mana yang bagus dan tidak bagus dan kemudian mendokumentasikan kebutuhan yang akan dipenuhi dalam sistem yang baru". Dengan demikian tahap analisis sistem dilakukan setelah tahap investigasi sistem dan sebelum tahap rancangan sistem. Tahap analisis sistem merupakan tahap yang kritis dan sangat penting karena kesalahan di tahap ini akan menyebabkan kesalahan pada tahap selanjutnya.

Menurut Tata Sutabri (2012:220) bahwa analisis sistem adalah "suatu prosedur yang dilakukan untuk pemeriksaan masalah dan penyusunan alternative pemecahan masalah yang timbul serta membuat spesifikasi sistem yang baru atau system yang akan diusulkan dan dimodifikasi”.

\section{METODE PENELITIAN}

Dalam menyelesaikan penelitian ini, penulis membutuhkan data - data yang akurat sesuai dengan judul pembahasan. Untuk mendapatkan data - data tersebut,maka penulis memiliki beberapa metode antara lain :
1. Penelitain Lapangan (Field Research) Penelitian lapangan yang penulis lakukan adalah dengan cara turun langsung ke Pondok Pesantren Ulakan Kec.Lubuk Tarok. Adapun kegiatan yang penulis lakukan dilapangan adalah sebagai berikut :

a) Wawancara (Interview)

Mewawancarai secara langsung setiap personil yang terlibat dalam pengolahan data Anakpondok pesantren.

b) Survei (Observation)

Melakukan pengamatan langsung terhadap sistem yang sedang berjalan saat ini, dengan melihat dokumen - dokumenanakpondok pesantren yang udah ada.

2. Penelitian Perpustakaan (Library Research)

Mengumpulkan referensi - referensi yang dapat menunjang penulis dalam menyusun penelitian ini.Dalam hal ini penulis mencari buku - buku yang berkaitan dengan judul praktek kerja lapangan yang sedang penulis lakukan dan penulis juga mencari referensi umum diinternet.

3. Penelitian Laboratorium (Laboratory Research)

Yaitu penelitian yang dilakukan dalam hal pengujian sistem yang dirancang untuk menghindari kesalahan - kesalahan (sistem Error) pada saat implementasi sistem.

\section{HASIL DAN PEMBAHASAN}

\section{A. Analisis Sistem Yang Sedang Berjalan}

Analisis merupakan kegiatan untuk menguraikan sistem yang utuh ke dalam bagian komponennya dengan maksud mengidentifikasi, sekaligus mengevaluasi permasalahan atau hambatan yang ada pada sistem serta merencanakan kebutuhan dalam perbaikan sistem. Memberikan solusi yang sesuai dengan kebutuhan yang sedang dibutuhkan. Dengan memberikan saran dan masukan 
yang dapat membantu untuk menyelesaikan masalah tersebut.

Sebelum penganalisaan atau perancangan sistem baru dilakukan, terlebih dahulu perlu dilihat sistem yang sedang berjalan saat ini. Hal ini dilakukan untuk mengetahui bagaimana sistem yang ada serta kendala-kendala apa yang dihadapi sehingga dapat diketahui kelemahan dan kelebihannya.

Pada proses pencatatan dan pengolahan data panti asuhan dilakukan dengan sistem manual, yakni masih menggunakan Microsoft Excel. Adapun aliran sistem Pondok Pesantren Ulakan Kec. Lubuk Tarok yang sedang berjalan pada saat ini dapat diuraikan sebagai berikut :

- Personil yang terlibat yaitu : pegawai, orang tua/wali, bagian administrasi, dan pimpinan.

- Pegawai memberikan data pegawai kepada bagian administrasi.

- $\quad$ Orang tua/wali memberikan data anak kepada bagian administrasi.

- Bagian administrasi menerima data pegawai yang di berikan pegawai.

- Bagian administrasi menerima data anak yang di berikan orang tua/wali.

- Bagian administrasi memproses data-data yang diterima dari pegawai dan orang tua/wali kedalam komputer dengan menggunakan aplikasi Microsoft Excel.

- Dari data : Data anak dan data pegawai menghasilkan laporan data anak, laporan data asrama anak, laporan, laporan data sekolah dan laporan data pegawai/Guru.

- Bagian administrasi menyerahkan laporan data anak, laporan data tempat tinggal anak di asrama, laporan data tempat tinggal/alamat anak, laporan data sekolah dan laporan data pegawai ke pimpinan masing-masing sebanyak 2 (dua) rangkap untuk disetujui.

- Pimpinan menerima laporan data anak, laporan data tempat tinggal anak di asrama, laporan data tempat tinggal/alamat anak, laporan data sekolah dan laporan data pegawai/guru dari bagian administrasi sebanyak 2 (dua) rangkap dan disetujui.

- Pimpinan menyerahkan laporan data anak, laporan data tempat tinggal anak di asrama, laporan data tempat tinggal/alamat anak, laporan data sekolah dan laporan data pegawai/guru yang telah disetujui rangkap 1(satu) ke bagian administrasi dan rangkap 1(satu) lagi diarsipkan.

- Bagian administrasi menerima laporan data anak, laporan data tempat tinggal anak di asrama, laporan data tempat tinggal/alamat anak, laporan data sekolah dan laporan data pegawai/guru rangkap 1 (satu) dari pimpinan yang telah disetujui untuk diarsipkan.

Untuk mengetahui gambaran lebih jelas dari sistem yang sedang berjalan saat ini di Pondok Pesantren Ulakan Kec. Lubuk Tarok maka dapat dilihat pada Gambar 1 berikut ini : 


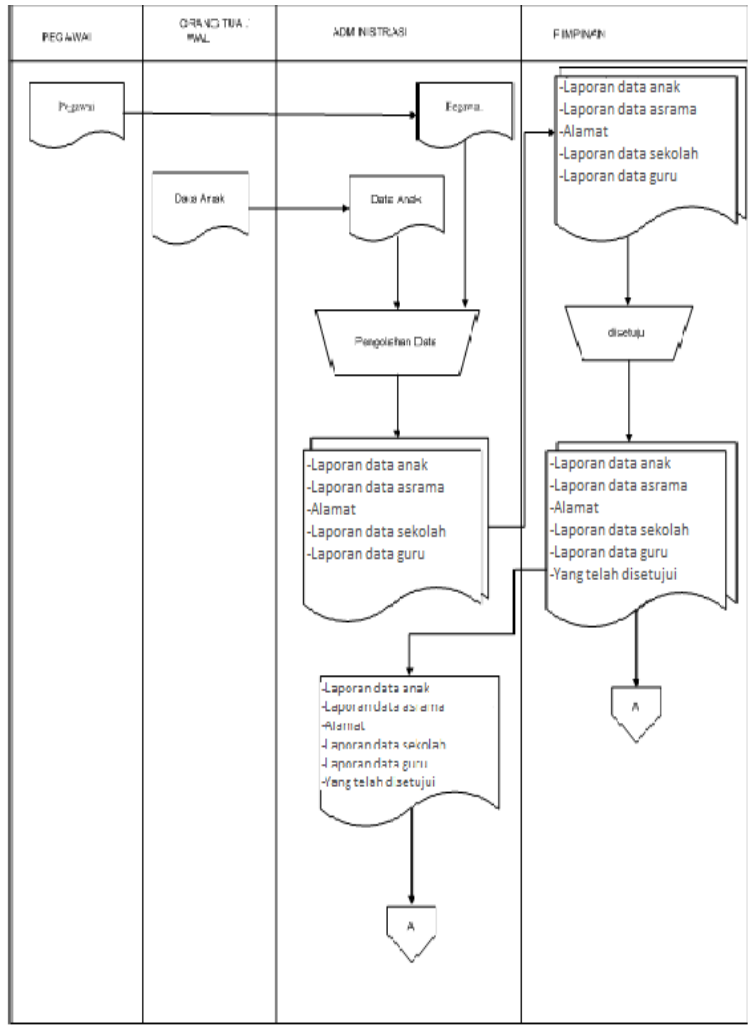

\section{Gambar 1. Aliran Sistem yang Sedang Berjalan}

Berdasarkan Gambar1 aliran sistem yang sedang berjalan terdapat beberapa kelemahan, diantaranya adalah :

- Pengolahan data anak panti asuhandalam pembuatan laporannya tidak menggunakan bahasapemrograman melainkan masihdengan menggunakan Microsoft Excel.

- Data pondok pesantren belum tersimpan dalam bentuk database sehingga dalam mencari data anak pondok pesantren membutuhkan waktu yang lama.

- Kurang akurat dalam pengolahan data sehingga informasi yang dihasilkan tidak tepat waktu.

Dari kelemahan-kelemahan diatas, maka diajukanlah usulan sistem baru yang diharapkan nantinya dapat mengatasi kelemahan-kelemahan yang ada, dan dapat menjawab semua kebutuhan-kebutuhan yang dibutuhkan suatu saat.

\section{B. Analisis Sistem yang Diusulkan}

Melihat cara kerja sistem yang sedang berjalan pada Pondok Pesantren Ulakan Kec. Lubk Tarok, memiliki banyak kelemahan dan kekurangan serta kendalakendala yang sering ditemui. Maka perlu diajukan sebuah sistem informasi yang bisa memperbaiki sistem pondok pesantren. Sistem informasi pengolahan data anak pondok pesantren, bisa mengurangi kesalahan-kesalahan dan kendala-kendala pada sistem lama. Berhubungan dengan diusulkannya sistem yang baru, yaitu dari sistem manual ke sistem yang terkomputerisasi, maka akan terjadi perubahan yaitu pada sistem yang baru memiliki entri data dan database, sementara pada sistem lama tidak memiliki entri data dan database, sebagai backup data yang telah disimpan.

Adapun prosedur aliran Sistem Informasi Pengolahan Data Pondok pesantren Ulakan Kec. Lubuk Tarok yang diusulkan adalah sebagai berikut :

- Personil yang terlibat yaitu : pegawai, orang tua/wali, bagian administrasi, dan pimpinan.

- Pegawai memberikan data pegawai kepada bagian administrasi.

- Orang tua/wali memberikan data anak kepada bagian administrasi.

- Bagian administrasi menerima data pegawai yang diberikan pegawai.

- Bagian administrasi menerima data anak yang di berikan orang tua/wali.

- Bagian administrasi mengolah data-data yang diterima dari orang tua/wali dandata dari pegawai yang ada pada bagian administrasi ke database.

- Dari data : Data anak dan data pegawai menghasilkan laporan data anak, laporan data tempat tinggal anak di asrama, laporan data tempat tinggal/alamat anak, 
laporan data sekolah dan laporan data pegawai/guru.

- Bagian administrasi menyerahkan laporan data anak, laporan data tempat tinggal anak di asrama, laporan data tempat tinggal/alamat anak, laporan data sekolah dan laporan data pegawai/guru ke pimpinan masing-masing sebanyak 2 (dua) rangkap untuk disetujui.

- Pimpinan menerima laporan data anak, laporan data tempat tinggal anak di asrama, laporan data tempat tinggal/alamat anak, laporan data sekolah dan laporan data pegawai/guru dari bagian administrasi sebanyak 2 (dua) rangkap dan disetujui.

- Pimpinan menyerahkan laporan data anak, laporan data tempat tinggal anak di asrama, laporan data tempat tinggal/alamat anak, laporan data sekolah dan laporan data pegawai/guru yang telah disetujui rangkap 1 (satu) ke bagian administrasi dan rangkap 1( satu) lagi diarsipkan.

- Bagian administrasi menerima laporan data anak, laporan data tempat tinggal anak di asrama, laporan data tempat tinggal/alamat anak, laporan data sekolah dan laporan data pegawai/guru rangkap 1 (satu) dari pimpinan yang telah disetujui untuk diarsipkan.

Untuk lebih jelasnya, aliran Sistem Informasi Pengolahan Data Pondok Pesantren Ulakan Kec. Lubuk Tarok yang diusulkan dapat dilihat pada Gambar 2 berikut ini :

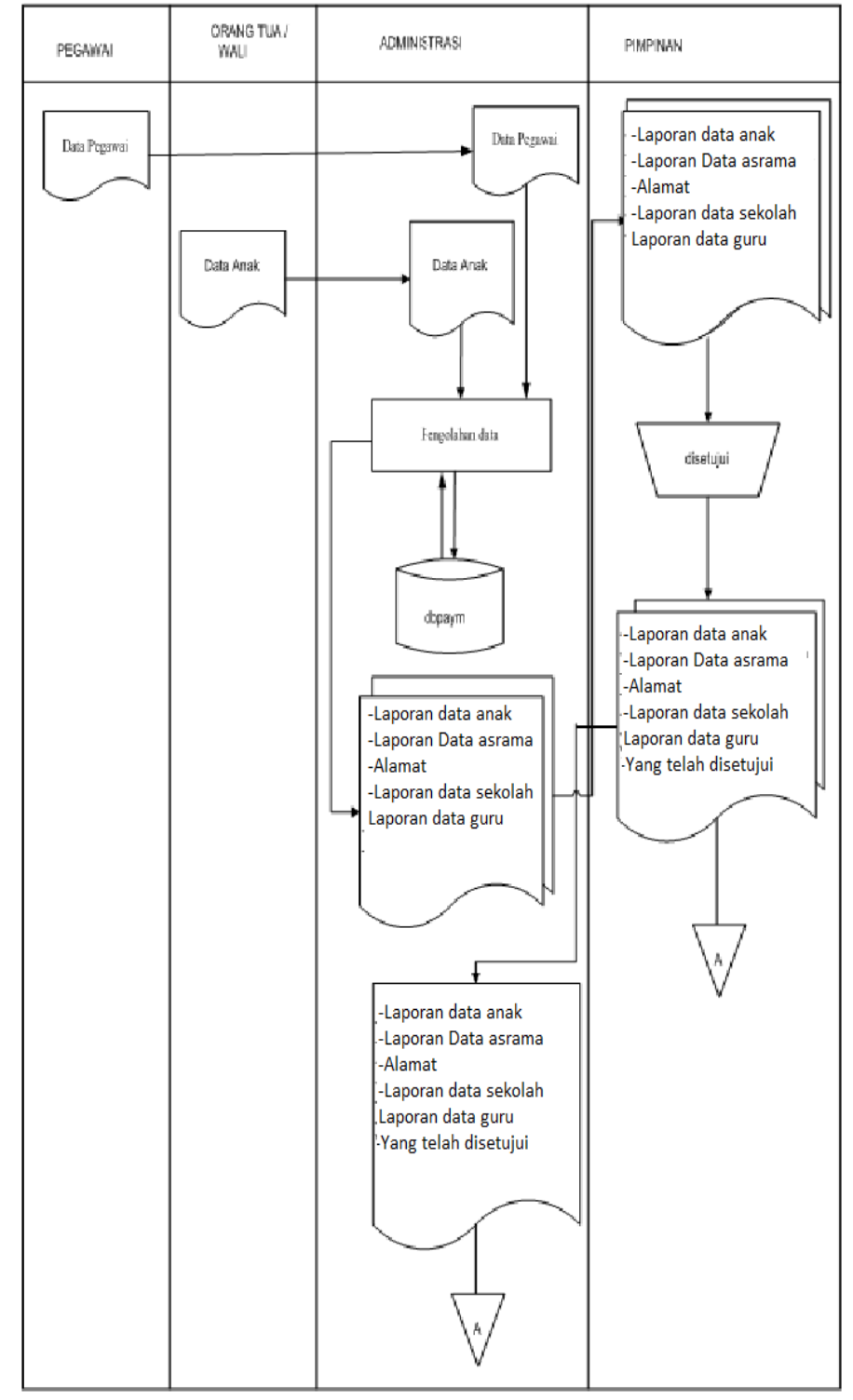

\section{Gambar 2. Aliran Sistem Informasi Yang Diusulkan}

Dari hasil analisis sistem yang diusulkan perubahan sistem pengolahan data menjadi sistem informasi memiliki keuntungan sebagai berikut:

- Pengolahan data sudah terkomputerisasi tidak lagi secara manual melainkan menggunakan program aplikasi, yaitu program aplikasi pondok pesantren dengan menggunakan bahasa pemograman PHP \&Database MySQL. 
- Pencarian data bisa dilakukan secara cepat dengan menggunakan fitur pencarian data yang ada dalam aplikasi.

- Keakuratan data lebih terjamin, lebih efesien, dan lebih efektif.

\section{Hasil Implementasi Sistem}

\section{Menu Login}

Halaman login bertujuan untuk membatasi hak akses pengguna atau user dalam menggunakan sistem yang ada. Dengan kata lain sistem ini hanya dapat digunakan oleh users tertentu yang sudah dikenal sistem. Untuk lebih jelasnya dapat dilihat pada Gambar 25 berikut ini:

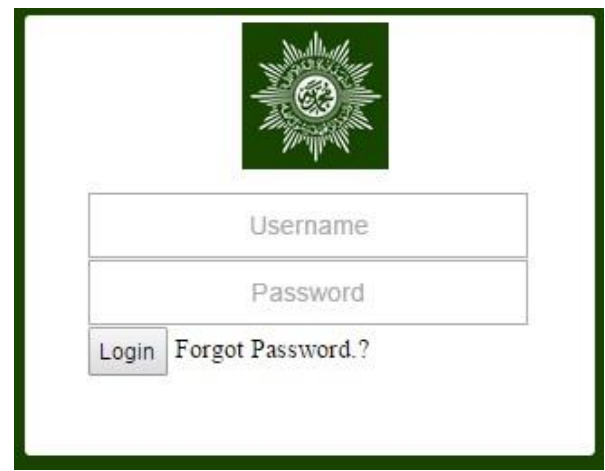

Gambar 25. Halaman Login User Sisfo Pondok Pesantren

\section{Menu Utama}

a) Menu Utama

Form menu utama merupakan kerangka dasar dari beberapa sub program yang ada didalamnya sebagai tampilan utama dari program Sistem Informasi Pengolahan Data Anak Pondok Pesantren Ulakan Kec. Lubuk Tarok. Untuk lebih jelasnya dapat dilihat pada Gambar 26 berikut ini:

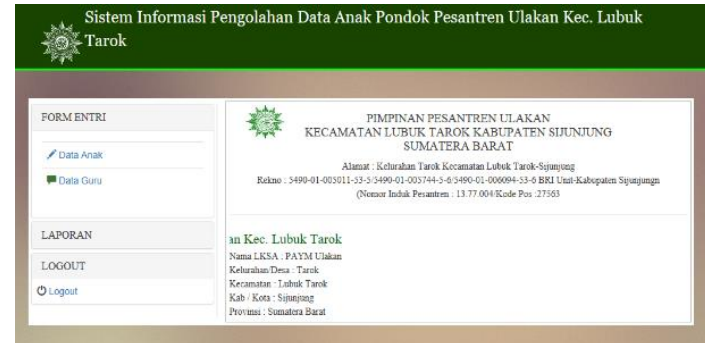

Gambar 26. Menu Utama Sistem Informasi Pengolahan Data Anak Pondok Pesantren Ulakan Kec. Lubuk Tarok

\section{Menu Form Entry}

a) Entry Data Anak

Entry data anak merupakan sub menu pertama dari menu entry data pada halaman administrator yang bertujuan untuk mengentrikan data anak pondok Pesantren. Pada halaman entri data anak terdapat form entry untuk memasukan data dan tombol simpan untuk proses penyimpanan ke dalam database serta tombol reset untuk mengosongkan isian form. Untuk lebih jelasnya dapat dilihat pada Gambar 27 berikut:

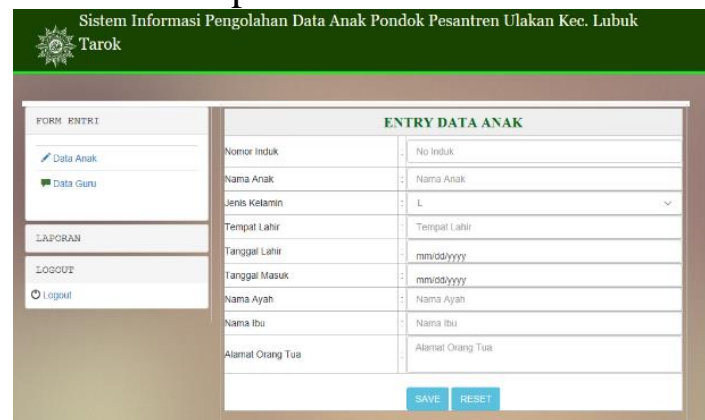

Gambar 27. Halaman Form Entry Data Anak

b) Entry Data Pegawai/Guru

Entry data pegawai merupakan sub menu ketiga dari menu form entry data pada halaman administrator yang bertujuan untuk memasukkan data pegawai. Pada halaman form entry data pegawai terdapat form entry untuk memasukkan data dan tombol simpan untuk proses penyimpanan data kedalam database dan tombol reset untuk menghapus isian dalam 
form. Untuk lebih jelas dapat dilihat pada Gambar 28 berikut :

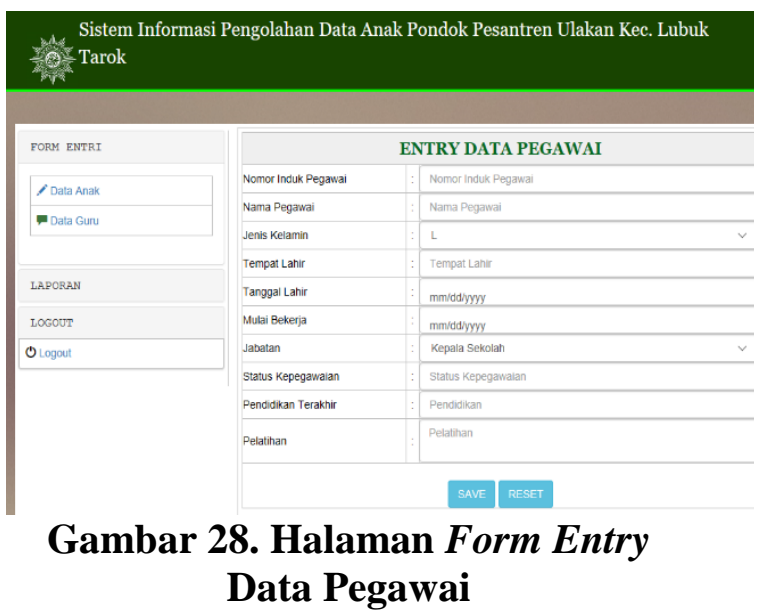

\section{Menu Laporan dan Output Lainnya \\ Laporan yang dihasilkan oleh} sistem informasi ini adalah laporan data anak, laporan data tempat tinggal anak di asrama, laporan data tempat tinggal/alamat anak, laporan sekolah anak, laporan pegawai/guru. Berikut laporan yang dihasilkan :

a) Laporan Data Anak Pondok Pesantren Ulakan Kec. Lubuk Tarok

Laporan Data Anak Pondok Pesantren Ulakan pada Sistem Informasi Pengolahan Data Anak Pondok Pesantren Ulakan Kec. Lubuk Tarok. Untuk lebih jelasnya dapat dilihat pada Gambar 29 berikut ini :

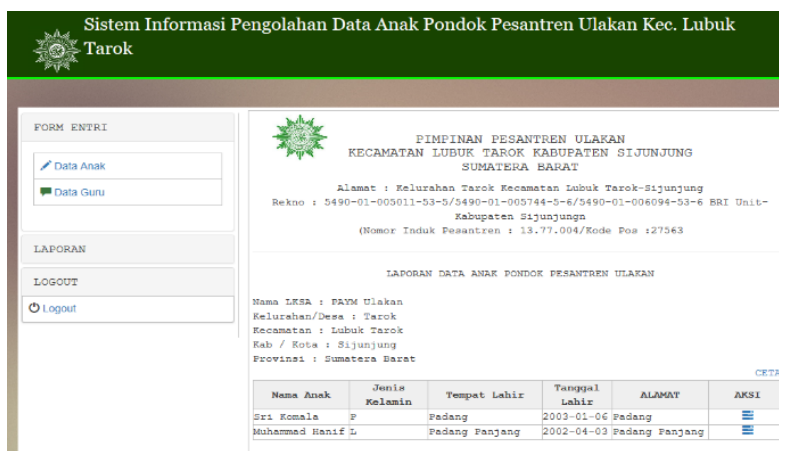

Gambar 29. Laporan Data Anak Pondok Pesantren Ulakan Kec. Lubuk Tarok b) Laporan Data Pegawai/Guru Pondok Pesantren Ulakan Kec. Lubuk Tarok Laporan Data Pegawai/Guru Pondok Pesantren pada Sistem Informasi Pengolahan Data Anak Pondok Pesantren Ulakan Kec. Lubuk Tarok dapat dilihat pada Gambar 30 berikut ini :

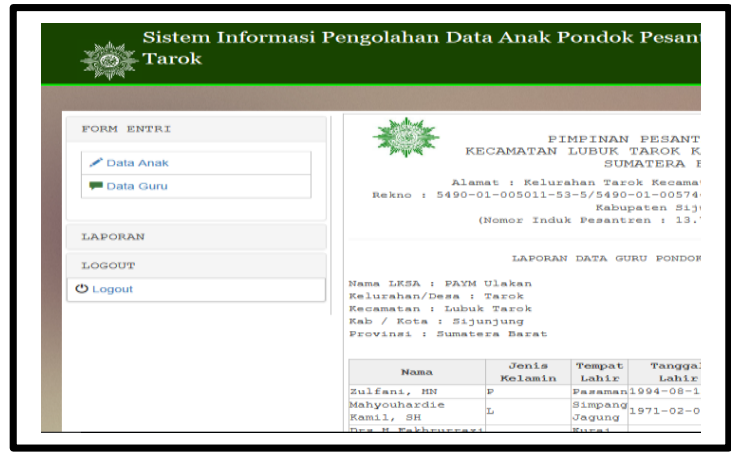

Gambar 30. Laporan Data Pegawai/Guru Pondok Pesantren Ulakan

\section{KESIMPULAN}

Setelah melakukan analisis dan pembahasan pada bagian sebelumnya berdasarkan Sistem Informasi Pengolahan Data Anak Pondok Pesantren Ulakan Kec.Lubuk Tarok maka dapat disimpulkan penulisan tugas praktek kerja lapangan ini sebagai berikut Dengan penerapan sistem yang baru pada Podok Pesantren, laporan pengolahan data yang dihasilkan menjadi lebih lebih efektif dan efesien, Sistem yang baru dapat mempermudah dan mempercepat proses kerja dari bagian administrasi dalam mengolah data yang ada pada Pondok Pesantren Ulakan Kec.Lubuk Tarok, Proses Pengarsipan dokumen yang teratur dan rapi sehingga meminimalisir kemungkinan untuk kehilangan data.

\section{DAFTAR PUSTAKA}

Al-Bahra bin Ladjamudin (2013). Analisa dan desain sistem informasi. Jogyakarta: Penerbit Graha Ilmu. 
Fatansyah. (2012). Basis Data. Bandung: Penerbit Informatika Bandung.

HM Jogiyanto. (2009). Sistem Teknologi Informasi: Pendekatan Terintegrasi: Konsep Dasar, Teknologi, Aplikasi, Pengembangan dan Pengelolaan. Yogyakarta: Penerbit CV. Andi Offset.

Kasiman Peranginangin. (2006). Aplikasi Web dengan PHP dan MySQL. Yokyakarta: Andi

Rusdiana, Irfan Moch. (2014). Sistem informasi Manajemen. Bandung: Penerbit CV. Pustaka Setia.

Sutabri Tata. (2012). Analisis Sistem Informasi. Yogyakarta: Penerbit CV. Andi Offset.

Sutabri Tata. (2013). Konsep Sistem Informasi. Yogyakarta: Penerbit CV. Andi Offset.

Sutanta Edhy. (2011). Basis Data. Yogyakarta: Penerbit CV. Andi Offset.
Rosa, Salahuddin. (2013). Rekayasa Perangkat Lunak Terstruktur dan berorientasi Objek. Bandung: Penerbit Informatika Bandung.

Sadeli Muhammad. (2013). Toko Baju Online dengan Php dan Mysql. Palembang: Penerbit Maxikom.

Riyanto (2014).Membuat Aplikasi Mini Market Integrasi Barcode Reader dengan Php dan Mysql. Yogyakarta: Penerbit Gava Media. Supardi yuniar (2010). Semua Bisa Jadi Programmer Visual FoxPro 9.0. Jakarta: Penerbit PT. Elex Media Komputindo.

Rosa, Salahuddin. (2013). Rekayasa Perangkat Lunak Terstruktur dan berorientasi Objek. Bandung: Penerbit Informatika Bandung.

http://www.psychologymania.com di akses tanggal 18 September 2014. http://dianpuspita.dosen.narotama.ac.id/ba han-ajar/ diakses tanggal 15 Januari 2015 